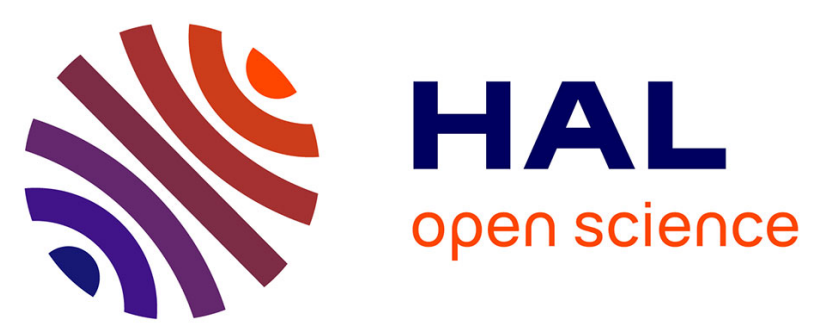

\title{
Constructing an allocation factor based on product- and process-related parameters to assess environmental burdens of producing value-added sludge-based products
}

Marilys Pradel, Lynda Aissani, Jean-Pierre Canler, Jean-Christophe Roux, Jonathan Villot, Jean-Christophe Baudez, Valérie Laforest

\section{To cite this version:}

Marilys Pradel, Lynda Aissani, Jean-Pierre Canler, Jean-Christophe Roux, Jonathan Villot, et al.. Constructing an allocation factor based on product- and process-related parameters to assess environmental burdens of producing value-added sludge-based products. Journal of Cleaner Production, 2018, 171, pp.1546-1557. 10.1016/j.clepro.2017.10.112 . emse-01617742

HAL Id: emse-01617742

https://hal-emse.ccsd.cnrs.fr/emse-01617742

Submitted on 16 May 2020

HAL is a multi-disciplinary open access archive for the deposit and dissemination of scientific research documents, whether they are published or not. The documents may come from teaching and research institutions in France or abroad, or from public or private research centers.
L'archive ouverte pluridisciplinaire HAL, est destinée au dépôt et à la diffusion de documents scientifiques de niveau recherche, publiés ou non, émanant des établissements d'enseignement et de recherche français ou étrangers, des laboratoires publics ou privés. 


\section{Constructing an allocation factor based on product- and process-related parameters to assess environmental burdens of producing value-added sludge- based products}

Marilys Pradel $^{\mathrm{a}, \mathrm{e}^{*}}$, Lynda Aissani ${ }^{\mathrm{b}, \mathrm{c}}$, Jean-Pierre Canler ${ }^{\mathrm{d}}$, Jean-Christophe Roux ${ }^{\mathrm{a}}$, Jonathan Villot ${ }^{\mathrm{e}}$, Jean-Christophe Baudez ${ }^{\mathrm{a}, \mathrm{f}}$, Valérie Laforest $\mathrm{t}^{\mathrm{e}}$

${ }^{\text {a } I r s t e a, ~ U R ~ T S C F, ~ D o m a i n e ~ d e s ~ P a l a q u i n s, ~} 40$ route de Chazeuil, 03150 MONTOLDRE, France, marilys.pradel@,irstea.fr, jean-christophe.roux@irstea.fr

b Irstea, UR OPAALE, 17 avenue de Cucillé, CS 64427, 35044 Rennes Cedex, France, lynda.aissani@irstea.fr, ${ }^{\mathrm{c}}$ Université Bretagne Loire, France,

d Irstea, UR MALY, centre de Lyon-Villeurbanne, 5 rue de la Doua, CS70077, FR-69626 Villeurbanne Cedex, France, jean-pierre.canler@irstea.fr

e Université de Lyon, Ecole Nationale Supérieure des Mines de Saint Etienne, CNRS, UMR 5600 EVS, 158 cours Fauriel, 42023 Saint-Etienne Cedex 2 France, valerie.laforest@mines-stetienne.fr, jonathan.villot@mines-stetienne.fr

${ }_{\mathrm{f}}^{\mathrm{f}}$ Luxembourg Institute of Science and Technology, Environmental Research and Innovation Department, 41, rue du Brill, L-4422 Belvaux, Luxembourg, jean-christophe.baudez@list.lu

*Corresponding author: telephone: (+33) 470474 426, fax: (+33) 470474 411, marilys.pradel@irstea.fr 


\section{Abstract}

Sludge is slowly moving away from providing basic by-products and towards providing value-added products (e.g. fertilisers); therefore, it is no longer perceived as waste but as a product. Consequently, wastewater treatment plants become multifunctional systems that produce two coproducts that are given a second life: sludge and "clean" water. An allocation factor in Life Cycle Assessment can partition environmental burdens of wastewater treatment between these two products, but doing so remains highly challenging. To address this challenge, we followed a four-step procedure to develop an allocation factor using a mesoscopic approach and process- and product-related parameters in a mathematical model. The first two steps consisted of determining and mathematically representing process- and product-related parameters and their associations to define a global allocation factor. The third step consisted of constructing a corrective inventory matrix to adjust the global allocation factor, since inventory flows can be specific to certain processes. The last step consisted of mathematical modelling of the final corrected allocation factor. Based on the parameters chosen, the global allocation factor equalled $45 \%$ for sludge and $55 \%$ for water. A sensitivity analysis was performed to assess the robustness of the sludge allocation factor, which varied from 39-49\%. The allocation factor developed reflects technological performances of the system and considers environmental impacts of sludge production to assess environmental impacts of value-added sludge-based products.

\section{Keywords}

Allocation factor, product-related parameter, process-related parameter, sludge, wastewater treatment, mathematical modelling 


\section{Introduction}

Reuse and recovery of matter or energy from municipal and industrial waste streams has gained increasing interest in the context of circular economy (CEC, 2017; MEEM, 2016) and the European Waste Framework Directive (CEC, 2008). The total amount of waste produced by domestic sources in France in 2015 was estimated at 33 million tons, which represents $14 \%$ of the total volume produced in Europe (Eurostat, 2017). Within this waste, wastewater sludge has potential utility, as it is a valuable source of organic matter and macronutrients such as nitrogen $(\mathrm{N})$, phosphorus (P) and potassium. Two main approaches are used to manage wastewater sludge in a more sustainable manner (Cieślik et al., 2015; Wang et al., 2008; Yoshida et al., 2013): "sludge-to-energy", which recovers energy, and "resource recovery", which recovers matter or nutrients. Depending on the technology used, both approaches provide sludge-based valueadded products. Research on sludge-to-energy approaches has increased over the past 10 years (Mills et al., 2014; Rulkens, 2008; Tyagi and Lo, 2013). The most common include:

- $\quad$ anaerobic digestion to produce biogas, which is converted into heat or electricity using a cogeneration system (Bond et al., 2012; Cao and Pawlowski, 2012), or purified into biomethane, which is injected into the natural gas network.

- $\quad$ biohydrogen production (Angenent et al., 2004; De Gioannis et al., 2013;Kalinci et al., 2009; Mudhoo et al., 2011).

- thermal conversion of sludge via pyrolysis or gasification to produce bio-oil or biodiesel (Bridle and Pritchard, 2004; Fonts et al., 2012). It also provides value-added products such as ceramsite (Xu et al., 2008) and adsorbents (Hadi et al., 2015; Smith et al., 2009).

- $\quad$ biofuel production (Kargbo, 2010; Manara and Zabaniotou, 2012; Siddiquee and Rohani, 2011).

Among nutrient recovery processes, P recovery is documented most frequently (Egle et al., 2015; Mehta et al., 2015). P can be recovered either via anaerobic stripping of sludge liquor by precipitating or crystallising phosphate as struvite or calcium phosphate or via anaerobic digestion of sludge after separating sludge particles and further treatment of the sludge liquor (Rahman et al., 2014). Thermal conversion can also recover P from sludge by producing biochar, which is a byproduct of pyrolysis (Bridle and Pritchard, 2004).

While some of these technologies exist only at laboratory or pilot scales, others are fully functional at the industrial scale, and there is growing willingness to increase the sustainability of sludge management via recovery processes and potentially marketable value-added products. Life Cycle Assessment (LCA) is often performed to assess environmental impacts of these ambitious sludge management systems (Johansson et al., 2008; Lederer and Rechberger, 2010; Mills et al., 2014; Remy, 2015). In these LCA studies, sludge is modelled mainly as waste, even when added-value products are produced. Thus, sludge is considered to have no environmental burden, which creates a distortion in comparative LCA. 
Reflecting on consequences for LCA of the paradigm shift in which sludge is considered a product instead of waste, Pradel et al. (2016) highlighted that system boundaries among scenarios become unequal when "product" sludge or "waste-to-product" sludge (after matter or nutrient recovery) is compared to fossil-based products such as chemical fertilizers. In LCA studies that compare sludge-based products to fossil or non-waste alternatives, the functional unit (i.e. the value to which LCA results are related to) focuses on a value-added product. In the paradigm shift, upstream processes of sludge production must be considered. Although sludge is a natural result of cleaning wastewater in wastewater treatment plants (WWTPs), it is not considered in the functional unit. To address this issue, environmental burdens must be allocated to sludge when treatments are oriented to produce value-added products. Doing so is challenging, however, because allocation factors must separate the environmental burdens of wastewater treatment between sludge and clean water for each process in the WWTP.

This article describes development of an allocation factor that partitions environmental burdens between sludge and treated water. Following a section on the allocation procedure in LCA and the mathematical calculations, the method for constructing this allocation factor based on process- and product-related parameters is described. Following this is a discussion on the limits and robustness of the allocation factor developed and choosing and determining the process- and product-related parameters. Several perspectives are provided on the possible use of this allocation method within the LCA allocation procedure.

\section{Allocation procedure in LCA}

LCA guidelines describe general principles for allocation (Heijungs and Suh, 2002; ISO, 2006a, b; ILCD Handbook, 2010), which are based on three main methodological points: definition of allocation factors (section 2.1.), the unit process considered (section 2.2), and how allocation is quantified through mathematical modelling (section 2.3).

\subsection{Constructing allocation factors based on relevant causal relationships}

Standards such as ISO 14044 and the ILCD Handbook state "where allocation cannot be avoided, the inputs and outputs of the system should be partitioned between its different products or functions in a way that reflects the underlying physical relationships between them; i.e. they should reflect the way in which the inputs and outputs are changed by quantitative changes in the products or functions delivered by the system". Therefore, allocation should be based on causal relationships. Ekvall and Tillman (1997) developed two categories of causal relationships: cause-oriented (between a system and its causes) and effect-oriented (between a system and its effects). We considered only the former because they 
help establish a relation between process functioning and product creation, which is appropriate for sludge production from wastewater treatment.

In practice, burdens are partitioned by identifying the relevant fractions of matter/energy ("input") and emissions/waste ("output") that should be allocated to each of the coproducts (Weidema, 2017). These fractions are called "allocation factors" or "partitioning coefficients" (Chen et al., 2010; Suh et al., 2010), the former of which we use hereafter.

Allocation factors are defined/supported by quantitative, measurable criteria that are usually based on relative amounts of each product, measured in units (i.e. partitioning criteria) such as mass, energy content or monetary value (Suh et al., 2010). Choosing appropriate criteria is controversial because no consensus exists on which ones are the most suitable (Curran, 2007a,b; ILCD Handbook, 2010). As illustrated by Hanes et al. (2015), "mass allocation works well in manufacturing processes but cannot be applied to energetic outputs ${ }^{1}$, such as electricity; energetic allocation is not intuitive for products not commonly quantified according to energy content; and economic allocation is problematic for products that are typically treated as waste and products with volatile prices."

Allocation factors should be designed in accordance with unique characteristics of each system and following "relevant physical relationships" (Pelletier et al., 2015). A relevant physical relationship is, for example, a physical property that represents the primary function defined for the coproduct considered and that is a reasonable common denominator for allocation among coproducts. In this way, the model directly quantifies environmental consequences of the function based on physical relationships between inputs and outputs (Marvuglia et al., 2010; Pelletier et al., 2015). Food production systems illustrate allocation factors that are based on physical relationships between system characteristics (Mackenzie et al., 2017). For example, allocation factors can be based on biophysical criteria such as metabolic energy flow or biological processes in livestock systems (IDF, 2010), or on the energy required to produce biomass (van der Werf and Nguyen, 2015). Food and Agriculture Organization guidelines (FAO, 2014) provide allocation factors for agricultural products and manure that consider the latter a coproduct instead of waste.

Industrial systems provide other examples. In the chemical industry, allocation factors are usually based on molar relationships (i.e. stoichiometry and molecular weights), enthalpy or exergy (Alvarez-Gaitan et al., 2013). According to Azapagic and Clift (1999a,b; 2000), the performance of an industrial system is based on product- and process-related parameters. These authors used linear programming to model physical relationships based on these parameters in a boron production system to model infinitesimal variations in outputs to determine "marginal allocation coefficients".

\footnotetext{
1 “energetic outputs" refers to energy products.
} 
For wastewater treatment, it is not relevant to base allocation factors on energy or economics. Because treated water has no energy content, energetic allocation would result in no allocation, while economic allocation would function only when both sludge and treated water had a market value (Pradel et al., 2016).

Treated water is usually measured by its volume (cubic meter or litre) and described by chemical parameters (e.g. chemical oxygen demand (COD), biochemical oxygen demand), while sludge is usually measured by its mass and dryness (kg or ton produced on a raw- or dry-matter basis). As treated water can also be measured by its mass (e.g. ton released per day or year), mass allocation would favour treated water over sludge because nearly all of the mass released is water. Indeed, a WWTP releasing 40000 tons of water and producing 10 tons of sludge per year will have a 100:0 mass allocation factor so that all the burdens will be allocated to clean water. Therefore, mass allocation is not appropriate for water treatment when both sludge and water are produced because it does not reflect the function of the system.

Traditional allocation factors for wastewater treatment have several disadvantages because they do not reflect system function or the potential to increase the efficiency of sludge production. The novelty of the present study is the development of an allocation factor that is based on process- and product-related parameters that circumvent these disadvantages. Because these parameters reflect process performance, any technological improvement in the latter will be mirrored in environmental impacts of each coproduct. Process-related parameters are operational or technical parameters that influence the functioning of the process to which they are related (e.g. temperature, pressure, reagent use efficiency). In contrast, product-related parameters are intrinsic parameters that directly influence product creation and composition within a process. Product-related parameters are specific to a process and are based on physical, chemical, biological or technical characteristics. Parameters based on a product's stoichiometric characteristics or specific macroelement capture rate can be used as product-related parameters. Indeed, from the moment the macro-element capture rate increases the concentration of an expected element in a product, it becomes a product-related parameter.

\subsection{Using a macroscopic to microscopic approach to determine an allocation factor}

Kim and Overcash (2000) highlighted that the definition of the unit process strongly influences the resulting allocation factors. The unit process can be defined from the largest process (i.e. the entire manufacturing system) - a "macroscopic" approach - to the smallest one (i.e. an operational engineering unit) - a "microscopic" approach. In the macroscopic approach, the process is not subdivided; thus, a single allocation factor is applied to all sub-processes regardless of their function. It is not feasible, however, to use either approach to determine an allocation factor for sludge production. The macroscopic approach requires mass, energy or economic allocation, none of which, as mentioned, is appropriate. The 
microscopic approach, in contrast, models each operational engineering unit, making it is difficult and time consuming to determine an allocation factor for each unit based on causal relationships.

An intermediate approach is "quasi-microscopic" (Kim and Overcash, 2000) (i.e. mesoscopic), in which the unit process refers to each sub-process, which can be combined or joint, physically separated or fully separated. This approach divides a process into sub-processes to identify underlying physical relationships (i.e. process- and product-related parameters) more easily. A sub-process includes all steps involved in manufacturing one product within a process. This approach is useful for identifying key issues related to a product or function and the sub-process concerned. Using the mesoscopic approach to determine an allocation factor is more suitable for sludge production because wastewater treatment is easily subdivided into sub-processes, each of which produces sludge. These sub-processes can be removal of carbon (C), N and P.

\subsection{Mathematical modelling used in the allocation procedure}

Mathematical modelling that considers a system's characteristics is often used to quantify allocation factors. Given system complexity and the mathematical structure of LCA, mathematical modelling takes the form of a matrix to address allocation in the Life Cycle Inventory (LCI) (Heijungs and Frischknecht, 1998; Heijungs and Suh, 2002). Matrices have been used to perform allocation when connecting LCA and Input-Output analysis (Majeau-Bettez et al., 2014; Suh et al., 2010) and to address the multifunctional problem caused by non-common products (Jung et al., 2013). Other authors have highlighted the ill-posed problem of allocation using the matrix notation (Cruze et al., 2014a; Hanes et al., 2015) or have improved the matrix-based approach by using regression with rectangular coefficient matrices (Cruze et al., 2014b; Marvuglia et al., 2010). Others have developed the matrix-based approach to improve uncertainty analysis of multifunctional systems using sensitivity coefficients (Jung et al., 2014; Wang and Work, 2014) or to assess uncertainty propagation in fuzzy LCI models (Heijungs and Tan, 2010).

As summarised by Heijungs (2010), the "inventory problem" refers to scaling all unit processes in the system in a way that exactly produces the reference flow (or functional unit). Scaling is performed in the LCI. The following generic formula is commonly used (Hanes et al., 2015; Heijungs and Suh, 2002; Jung et al., 2013):

$$
\mathrm{g}=\mathrm{B} \cdot \mathrm{A}^{-1} \cdot \mathrm{f} \quad(\text { Eq. } 1)
$$

where vector $\mathrm{g}$ refers to LCI results (i.e. environmental flows, as rows in a single column), B is the intervention matrix (with environmental flows as rows and processes as columns), $\mathrm{A}^{-1}$ is the technology matrix (with processes as rows and economic flows as columns), and vector $\mathrm{f}$ is the functional unit defined in the goal and scope (with economic flows as rows in a single column). 
Multifunctional processes have more products than processes, which makes matrix A is rectangular; consequently, matrix $\mathrm{A}^{-1}$ does not exist, and Eq. 1 cannot be applied. One solution is to expand matrix A using partitioning allocation so that it will represent monofunctional processes and become square. An allocation factor (C) (Jung et al., 2014) can be used to convert matrices $\mathrm{A}$ and $\mathrm{B}$ into their allocated forms $A_{*}$ and $B_{*}$.

When allocation factor $\mathrm{C}$ is used to partition economic and environmental flows, Eq. 1 becomes:

$$
\mathrm{g}_{*}=\mathrm{B}_{*} \cdot \mathrm{A}_{*}^{-1} \cdot \mathrm{f}
$$

Allocated inventory results $g_{*}$ are then converted into environmental impacts $\left(\mathrm{h}_{*}\right)$ by multiplying them by a matrix of characterisation factors $(\mathrm{Q})$ :

$$
\mathrm{h}_{*}=\mathrm{Q} \cdot \mathrm{g}_{*} \quad(\text { Eq. } 3)
$$

Jung et al. (2014) argued that allocation factor C is a potential source of uncertainty, and Hanes et al. (2015) argued that it can be calculated from common partitioning criteria or other criteria. The purpose of mentioning these articles was to explore a theoretical allocation procedure. The purpose of the present study was to determine a value for allocation factor C for wastewater treatment. Therefore, we developed a mathematical model, based on process- and product-related parameters and a mesoscopic approach, to allocate environmental burdens between sludge and treated water.

\section{Constructing an allocation factor for wastewater treatment}

It was first necessary to identify sub-processes involved in wastewater treatment and the related process- and productrelated parameters used to construct the allocation factor.

\subsection{Modelling a wastewater treatment plant}

A WWTP generally consists of two processes that treat wastewater and sludge, respectively. For the former, the most common one is the aerobic activated sludge process. In its most complete form, wastewater is progressively cleaned in three sub-processes, according to a mesoscopic approach, to remove organic $\mathrm{C}, \mathrm{N}$ and $\mathrm{P}$ before being released into the environment.

Organic $\mathrm{C}$ is removed by bacteria, whose growth and decay degrade soluble organic matter. The bacteria grow by using oxygen to consume the organic matter. Autolysis of bacteria causes them to decay, which also uses oxygen. During their growth, bacteria also consume ammonium $\left(\mathrm{NH}_{4}^{+}\right)$and $\mathrm{P}$. The remaining $\mathrm{N}$ is removed by nitrification, oxidation of ammonia $\left(\mathrm{NH}_{4}^{+}\right)$to nitrite $\left(\mathrm{NO}_{2}^{-}\right)$and nitrate $\left(\mathrm{NO}_{3}^{-}\right)$, and denitrification, reduction of $\mathrm{NO}_{2}^{-}$and $\mathrm{NO}_{3}^{-}$into nitrogen gas 
$\left(\mathrm{N}_{2}\right)$ (Degrémont, 2005). P that is not assimilated within bacteria (i.e. "normal" biological P removal (NBPR)) can be removed by two processes: chemical precipitation and enhanced biological P removal (EBPR). When NBPR is unable to decrease $\mathrm{P}$ concentrations below legal thresholds, chemical precipitation is required. It consists of adding chemical salts to produce chemical sludge such as iron (III) phosphate or aluminium phosphate when ferric chloride or aluminium sulphate is respectively used. EBPR is similar to NBPR but includes an anaerobic phase before the aerobic phase. Sludge from EBPR has higher P concentration (6\%) than that from NBPR (1.5\%). Together, the three sub-processes of C, N and P removal produce biological sewage sludge (Fig. 1). Afterwards, the environmental impacts of sludge treatment are fully allocated to the sludge-based product.

\subsection{Determining which parameters to use to construct the allocation factor}

This section presents how process- and product-related parameters are determined. After a brief description, a wastewater treatment case study is used to explain and illustrate the calculation of the process- and product-related parameters.

\subsubsection{Process-related parameters}

\section{Description}

A process-related parameter can be specific to only one sub-process or can contribute to several sub-processes. In the latter case, its contributions among sub-processes can be weighted by a ratio that equals the proportion of each processrelated parameter used by each sub-process in the entire process. The ratio is calculated by dividing the value of a characteristic (e.g. mass, volume) involved in each sub-process by the total value of the characteristic involved in the entire system.

The process-related parameter is noted $\mathrm{j}$ and ranges from 1 to $\mathrm{n}$. The sub-process is noted $\mathrm{k}$ and ranges from 1 to $\mathrm{p}$. The relation between the sub-process and the process-related parameter is noted $\beta_{\mathrm{j}, \mathrm{k}} \cdot \beta_{\mathrm{j}, \mathrm{k}}$ is calculated according to Eq. 4 and refers to the ratio used to partition each process-related parameter $\mathrm{j}$ between each sub-process $\mathrm{k}$ using it.

$$
\beta_{\mathrm{j}, \mathrm{k}}=\frac{\mathrm{Q}_{\mathrm{j}, \mathrm{k}}}{\sum_{\mathrm{k}=1}^{\mathrm{p}} \mathrm{Q}_{\mathrm{j}, \mathrm{k}}} \quad(\text { Eq. } 4)
$$

where $Q_{j, k}$ is the value of the process-related parameter used by each sub-process $k$, and $\sum_{k=1}^{p} Q_{j, k}$ is the total value of process-related parameters used by all sub-processes $\mathrm{k}$. 
When a process-related parameter contributes to only one sub-process, $\beta_{\mathrm{j}, \mathrm{k}}$ equals 1 . When it contributes to several subprocesses, $\beta_{\mathrm{j}, \mathrm{k}}$ ranges from 0 to 1 (exclusive), and the sum of $\beta_{\mathrm{j}, \mathrm{k}}$ equals 1 .

\section{Wastewater treatment process-related parameters}

According to expert opinion, oxygen demand (OD) and the shift between aerobic and anaerobic periods are the processrelated parameters that most influence these processes of wastewater treatment.

$\mathrm{OD}$ equals the amount of oxygen required during $\mathrm{C}$ and $\mathrm{N}$ removal. In contrast, $\mathrm{P}$ removal does not require oxygen because the bacteria have already assimilated oxygen. Values for calculating each process-related parameter are provided in Table 1 and detailed in Supplementary Information. Values come from literature and are related to standard oxygen requirement for $\mathrm{C}$ and $\mathrm{N}$ removal. $\mathrm{OD}$ of $\mathrm{C}$ removal equals that used for direct oxidation of organic matter (via bacterial growth) and indirect oxidation from bacterial autolysis (decay) (Degrémont, 2005). OD of N removal equals that used to oxidise $\mathrm{NH}_{4}{ }^{+}$during nitrification. The $\mathrm{OD}$ ratio $\left(\beta_{O D}\right.$, Eq. 5) for $\mathrm{C}$ and $\mathrm{N}$ equals the $\mathrm{OD}$ for the removal of each nutrient $\left(\mathrm{OD}_{\text {nutrient removal }}\right)$ divided by the total $\mathrm{OD}\left(\mathrm{OD}_{\mathrm{total}}\right)$.

$$
\beta_{O D}=\frac{O D_{\text {nutrient removal }}}{O D_{\text {total }}} \quad \text { (Eq. 5) }
$$

To optimise $\mathrm{C}$ and $\mathrm{P}$ removal and nitrification (which require oxygen) and denitrification (which requires a lack of oxygen), wastewater is subjected to alternating aerobic and anaerobic periods (AAP). AAP is most effective when the aerobic period lasts $16 \mathrm{~h}$, leaving $8 \mathrm{~h}$ in the $24 \mathrm{~h}$ cycle for complete denitrification (J.-P. Canler, Irstea, pers. comm.). AAP ratios for the four $\mathrm{C}, \mathrm{N}$ and $\mathrm{P}$ removal processes $\left(\beta_{A A P}, \mathrm{Eq} .6\right)$ are calculated to partition the $24 \mathrm{~h}$ cycle. They equal the proportion of the complete cycle under an aerobic condition $(\%$ aerobic period $)$ divided by the number of sub-processes under that condition $\left(n_{\text {aerobic operation }}\right)$ plus the proportion of the complete cycle under an anaerobic condition $(\%$ anoxic period $)$ divided by the number of sub-processes under that condition $\left(n_{\text {anoxic operation }}\right)$.

$$
\beta_{A A P}=\frac{\%_{\text {aerobic period }}}{n_{\text {aerobic operation }}}+\frac{\%_{\text {anoxic period }}}{n_{\text {anoxic operation }}} \quad \text { (Eq. 6) }
$$

\subsubsection{Product-related parameters}

\section{Description}

As a sub-process can produce two or more coproducts simultaneously, product-related parameters, like process-related parameters, can be integrated into the allocation factor via ratios, in this case based on physical, chemical or stoichiometric 
properties. The sub-process is noted $\mathrm{k}$ and ranges from 1 to $\mathrm{p}$. Coproducts of the sub-process are noted $\mathrm{r}$ and range from 1 to q. The relation between sub-processes and products is based on the product-related parameter and is codified with a $\alpha$ symbol. The ratio $\left(\alpha_{\mathrm{k}, \mathrm{r}}\right)$ is calculated according to Eq. 7.:

$$
\alpha_{\mathrm{k}, \mathrm{r}}=\frac{\mathrm{Q}_{\mathrm{k}, \mathrm{r}}}{\sum_{\mathrm{k}=1}^{\mathrm{p}} \mathrm{Q}_{\mathrm{k}, \mathrm{r}}} \quad(\text { Eq. } 7)
$$

where $Q_{k, r}$ is the value of product-related parameters used to generate each product $r$, and $\sum_{k=1}^{p} Q_{k, r}$ is the total value of product-related parameters used by the sub-process $\mathrm{k}$.

When a product-related parameter contributes to only one product, $\alpha_{k, r}$ equals 1 . When it contributes to several coproducts, $\alpha_{\mathrm{k}, \mathrm{r}}$ ranges from 0 and 1 (exclusive), and the sum of $\alpha_{\mathrm{k}, \mathrm{r}}$ equals 1 .

\section{Wastewater treatment product-related parameters}

Sludge production resulting from $\mathrm{C}$ and $\mathrm{N}$ removal is based on stoichiometric equations, while that from $\mathrm{P}$ removal is based on chemical precipitation and bacterial assimilation. Values and equations used to calculate each product-related parameter were determined according to expert opinion (Table 2 and Supplementary Information).

\section{Carbon removal}

Average compositions of organic matter in wastewater and sludge were assumed to be $\mathrm{C}_{18} \mathrm{H}_{19} \mathrm{NO}_{9}$ and $\mathrm{C}_{5} \mathrm{H}_{7} \mathrm{NO}_{2}$, respectively (Deronzier et al., 2001; Hahn, 2012). Bacteria degrade organic matter via growth (Eq. 8) and decay (endogenous respiration) (Eq. 9):

$$
\begin{aligned}
\mathrm{C}_{18} \mathrm{H}_{19} \mathrm{NO}_{9}+8.8 \mathrm{O}_{2}+0.74 \mathrm{NH}_{3}=>9.3 \mathrm{CO}_{2}+1.74 \mathrm{C}_{5} \mathrm{H}_{7} \mathrm{NO}_{2}+4.52 \mathrm{H}_{2} \mathrm{O} \\
0.87 \mathrm{C}_{5} \mathrm{H}_{7} \mathrm{NO}_{2}+4.35 \mathrm{O}_{2}=>4.35 \mathrm{CO}_{2}+0.87 \mathrm{NH}_{3}+1.74 \mathrm{H}_{2} \mathrm{O}
\end{aligned}
$$

The product-related parameter for $\mathrm{C}$ removal $\left(\alpha_{C}\right)$ is based on the $\mathrm{C}$ contents of sludge and wastewater, and the amount of sludge produced per gram of COD eliminated $\left(m_{C, \text { sludge }}\right)$. After calculating $m_{C, s l u d g e}, \alpha_{C}$ is calculated as $\mathrm{m}_{\mathrm{C}, \text { sludge }}$ times the proportions of $\mathrm{C}$ in sludge $\left(\%_{C, \text { sludge }}\right)$ and wastewater $\left(\%_{C, \text { wastewater }}\right)$ per g of COD eliminated $\left(\mathrm{m}_{\mathrm{C}, \text { wastewater }}\right)$ :

$$
\begin{gathered}
\alpha_{C}=\frac{m_{C, \text { sludge }} \cdot \%_{C, \text { sludge }}}{m_{C, \text { wastewater }} \cdot \%_{C, \text { wastewater }}} \quad \text { (Eq. 10) } \\
\text { with } m_{C, \text { sludge }}=\frac{1.74 \cdot m_{\text {biomass }}}{\left(n_{O 2, \text { decay }}+n_{O 2, \text { synthesis }) \cdot 32}\right.} \text { expressed in } \mathrm{g} / \mathrm{g} \text { COD }
\end{gathered}
$$


where $n_{O 2, \text { decay }}$ is moles of $\mathrm{O}_{2}$ for decay, $n_{O 2 \text {,synthesis }}$ refers to the moles of $\mathrm{O}_{2}$ for growth, $m_{\text {biomass }}$ refers to the biomass molar mass (i.e. sludge), and 1.74 refers to the moles of sludge in Eq. 8.

\section{$\underline{\text { Nitrogen removal }}$}

Nitrification and denitrification produce sludge according to the following stoichiometric equations (Eq. 11 and 12 , respectively) (Deronzier et al., 2001; Qasim, 1998):

$$
\begin{gathered}
\mathrm{NH}_{4}^{+}+1.83 \mathrm{O}_{2}+1.98 \mathrm{HCO}_{3}^{-}=>0.021 \mathrm{C}_{5} \mathrm{H}_{7} \mathrm{NO}_{2}+0.98 \mathrm{NO}_{3}^{-}+1.88 \mathrm{H}_{2} \mathrm{CO}_{3}+1.041 \mathrm{H}_{2} \mathrm{O} \\
\mathrm{NO}_{3}{ }^{-}+0.135 \mathrm{C}_{18} \mathrm{H}_{19} \mathrm{NO}_{9}+0.08 \mathrm{NH}_{4}^{+}+0.92 \mathrm{H}_{3} \mathrm{O}^{+}=>0.222 \mathrm{C}_{5} \mathrm{H}_{7} \mathrm{NO}_{2}+0.5 \mathrm{~N}_{2}+1.33 \mathrm{CO}_{2}+2.06 \mathrm{H}_{2} \mathrm{O}
\end{gathered}
$$

These two equations are used to calculate the product-related parameter for sludge production from $\mathrm{N}$ removal $\left(\alpha_{N}\right.$, Eq. 13). As $\mathrm{N}$ removal requires an organic substrate, the corresponding ratio is based on the $\mathrm{N}$ and $\mathrm{C}$ contents of sludge compared to total $\mathrm{N}$ and $\mathrm{C}$ output. It is the sum of the number of $\mathrm{N}$ moles from biomass produced from nitrification $\left(\mathrm{n}_{\mathrm{N}, \text { sludge }}\right)$ and the number of $\mathrm{C}$ and $\mathrm{N}$ moles from biomass produced from denitrification $\left(\mathrm{n}_{\mathrm{C}, \mathrm{N}, \text { sludge,DN }}\right)$. This sum is then divided by the total number of $\mathrm{C}$ and $\mathrm{N}$ moles produced from denitrification, assuming a 0.98 correction factor (i.e. amount of $\mathrm{NO}_{3}{ }^{-}-\mathrm{N}$ produced from nitrification, $\left.\mathrm{n}_{\mathrm{C}, \mathrm{N}, \text { total }}\right)$.

$$
\begin{gathered}
\alpha_{N}=\frac{n_{N, \text { sludge }}+n_{C, N, \text { sludge }, D N}}{n_{C, N, \text { total }}} \\
\text { with } n_{C, N, \text { sludge,DN }}=n_{N, N O 3} \cdot\left(\left(n_{c, \text { biomass }}+n_{n, \text { biomass }}\right) \cdot n_{D N, \text { sludge }}\right) \\
\text { and } n_{C, N, \text { total }}=n_{C, N, \text { sludge }, D N}+n_{N, N O 3} \cdot\left(\left(n_{n, N 2} \cdot n_{D N, N 2}\right)+n_{D N, C O 2}\right)
\end{gathered}
$$

where $n_{N, N O 3}$ is moles of $\mathrm{NO}_{3}{ }^{-}$from nitrification, $n_{N, \text { sludge }}$ is moles of biomass from nitrification, $n_{D N, N 2}$ is moles of $\mathrm{N}_{2}$ from denitrification, $n_{D N, C O 2}$ is moles of $\mathrm{CO}_{2}$ from denitrification, $n_{D N, \text { sludge }}$ is moles of sludge from denitrification, $n_{c, \text { biomass }}$ is the number of $\mathrm{C}$ atoms in the biomass, $n_{n, \text { biomass }}$ is the number of $\mathrm{N}$ atoms in the biomass, and $n_{n, N 2}$ is the number of $\mathrm{N}$ atoms in $\mathrm{N}_{2}$.

\section{Phosphorus removal}

Sludge produced from phosphorus removal is the results from two operations of the phosphorus assimilation within the bacteria (both NBPR and EBPR can be considered) and an additional chemical precipitation. Additional chemical precipitation is required when phosphorus removal is not sufficient to meet the required phosphorus concentrations to be 
released within the natural media. $\mathrm{P}$ assimilation $\left(R E_{\text {assimilation }}\right)$ depends on the COD:P ratio of incoming wastewater and the food-to-mass (F:M) ratio. $R E_{\text {assimilation }}$ ranges from $20-60 \%$ at a $\mathrm{F}: \mathrm{M}$ ratio of 0.1 , depending on the COD:P ratio and whether NBPR or EBPR is performed (Stricker and Héduit, 2010). We assumed a value of 30\%, which corresponds to NBPR (J.-P. Canler, Irstea, pers. comm.). Chemical precipitation of P (RE $\left.\mathrm{R}_{\text {chemical }}\right)$ uses chemical salts. We assumed only an iron-based reactant because it is commonly used in water treatment. $\mathrm{RE}_{\text {chemical }}$ (Eq. 14) is a function of $\mathrm{P}$ concentration of incoming wastewater and the molar Fe:P ratio (range = 0.25-4.00) (Canler and Choubert, 2007).

$$
\mathrm{RE}_{\text {chemical }}=(27.717 \cdot \ln (\text { molar Fe: } \text { P ratio })+50.776) / 100
$$

The product-related parameter for sludge production from $\mathrm{P}$ removal $\left(\alpha_{P}\right.$, Eq. 15) equals $\mathrm{RE}_{\text {assimilation }}$ plus $\mathrm{RE}_{\text {chemical }}$, assuming a molar Fe:P ratio of 1.8 because chemical precipitation of $\mathrm{P}$ required $70 \%$ efficiency:

$$
\alpha_{P}=R E_{\text {assimilation }}+\left(\left(1-R E_{\text {assimilation }}\right) \cdot R E_{\text {chemical }}\right) \quad(\text { Eq. 15) }
$$

\subsection{Constructing the allocation factor $\mathrm{C}_{\text {sludge }}$}

Combining these independent process- and product-related parameters ( $\beta_{\mathrm{j}, \mathrm{k}}$ and $\alpha_{\mathrm{k}, \mathrm{r}}$, respectively; Fig. 2a) for coproducts $r$ yields the allocation factor $C_{r}$, which we applied to the wastewater treatment case study (Fig. 2b). $C_{r}$ was developed in a four-step procedure: mathematically representing process- and product-related parameters (step 1), constructing a global allocation factor $C_{g}$, (step 2), determining a corrective inventory matrix I (step 3) and finalising $C_{r}($ step 4$)$.

\subsubsection{Step 1. Mathematical representation of process- and product-related parameters}

\section{Equations}

The process-related parameter influences each sub-process $\mathrm{k}\left(\beta_{\mathrm{j}, \mathrm{k}}\right)$, and the product-related parameter influences the creation of each coproduct $\mathrm{r}\left(\alpha_{\mathrm{k}, \mathrm{r}}\right)$. Process-related parameters are expressed as the sum of their contribution ratios to each sub-process k (Eq. 16).

$$
\delta_{\mathrm{k}}=\sum_{\mathrm{j}=1}^{\mathrm{n}} \beta_{\mathrm{j}, \mathrm{k}} \quad(\text { Eq. } 16)
$$

As ratios must range from 0 to $1, \delta_{\mathrm{k}}$ is scaled down by dividing it by the total number of process-related parameters $\mathrm{n}$, which makes $\delta^{\prime}{ }_{\mathrm{k}}$ a single-row matrix (Eq. 17):

$$
\delta_{\mathrm{k}}^{\prime}=\frac{\sum_{\mathrm{j}=1}^{\mathrm{n}} \beta_{\mathrm{j}, \mathrm{k}}}{\mathrm{n}} \quad\left(\text { Eq. 17) } \quad \text { with } \sum_{k=1}^{p} \delta_{k}^{\prime}=1\right.
$$

Product-related parameters are represented in matrix P, with terms $\alpha_{\mathrm{k}, \mathrm{r}}$ : 


$$
\mathrm{P}=\left(\begin{array}{ccccc}
\alpha_{1,1} & \ldots & \alpha_{1, \mathrm{r}} & \ldots & \alpha_{1, \mathrm{q}} \\
\vdots & \ddots & \vdots & \ddots & \vdots \\
\alpha_{\mathrm{k}, 1} & \ldots & \alpha_{\mathrm{k}, \mathrm{r}} & \ldots & \alpha_{\mathrm{k}, \mathrm{q}} \\
\vdots & \ddots & \vdots & \ddots & \vdots \\
\alpha_{\mathrm{p}, 1} & \ldots & \alpha_{\mathrm{p}, \mathrm{r}} & \ldots & \alpha_{\mathrm{p}, \mathrm{q}}
\end{array}\right) \text { with } 1 \leq \mathrm{r} \leq \mathrm{q} \text { and } 1 \leq \mathrm{k} \leq \mathrm{p}
$$

\section{Application to wastewater treatment parameters}

For wastewater treatment, the contribution ratio of each process-related parameter of each sub-process was then calculated using the process-related parameter calculated in the previous section (Table 1):

$$
\delta^{\prime}{ }_{C}=\frac{\beta_{O D, C}+\beta_{A A P, C}}{n}=0.422 ; \delta^{\prime}{ }_{N}=\frac{\beta_{O D, N}+\beta_{A A P, N}}{n}=0.467 ; \delta_{P}^{\prime}=\frac{\beta_{A A P, P}}{n}=0.111
$$

Thus, $\delta^{\prime}{ }_{\mathrm{k}}=\left(\begin{array}{lll}0.422 & 0.467 & 0.111\end{array}\right)$

Next, the contribution ratio of each product-related parameter was calculated (Table 2):

$$
P=\left(\begin{array}{ll}
\alpha_{\mathrm{C}, \text { sludge }} & \alpha_{\mathrm{C} \text {,water }} \\
\alpha_{\mathrm{N}, \text { sludge }} & \alpha_{\mathrm{N} \text {,water }} \\
\alpha_{\mathrm{P}, \text { sludge }} & \alpha_{\mathrm{P}, \text { water }}
\end{array}\right)=\left(\begin{array}{ll}
0.451 & 0.549 \\
0.365 & 0.635 \\
0.769 & 0.231
\end{array}\right)
$$

\subsubsection{Step 2. Constructing a global allocation factor $\mathrm{C}_{\mathrm{g}}$}

The global allocation factor $\mathrm{C}_{\mathrm{g}}$ was constructed by multiplying $\delta^{\prime}{ }_{\mathrm{k}}$ by matrix $\mathrm{P}$ (Eq. 18). The result is a matrix composed of $\delta^{\prime}{ }_{\mathrm{k}} \alpha_{\mathrm{k}, \mathrm{r}}$ terms that allocates each environmental burden to the product and sub-process from which it originated.

$$
\begin{gathered}
\mathrm{C}_{\mathrm{g}}=\delta^{\prime}{ }_{\mathrm{k}} \cdot \mathrm{P}=\delta^{\prime}{ }_{\mathrm{k}} \alpha_{\mathrm{k}, \mathrm{r}} \quad \text { (Eq. 18) } \\
\text { with } 1 \leq \mathrm{k} \leq \mathrm{p}, 1 \leq \mathrm{r} \leq \mathrm{q} \text { and } \sum_{\mathrm{k}=1}^{\mathrm{p}} \sum_{\mathrm{r}=1}^{\mathrm{q}}\left(\delta^{\prime}{ }_{\mathrm{k}} \alpha_{\mathrm{k}, \mathrm{r}}\right)=1
\end{gathered}
$$

$\mathrm{C}_{\mathrm{g}}$ took the following form for wastewater treatment:

$$
C_{g}=\left(\begin{array}{ll}
0.191 & 0.232 \\
0.170 & 0.296 \\
0.085 & 0.026
\end{array}\right)
$$

\subsubsection{Step 3. Determining a corrective inventory matrix I}

Economic and environmental flows are used or created by one or more sub-processes, while others are used or generated by the entire process (i.e. all sub-processes). A corrective inventory matrix I, with terms $\lambda_{\mathrm{i}, \mathrm{k}}$, is created to adjust $\mathrm{C}_{\mathrm{g}}$ by specifying whether inputs/outputs $\mathrm{i}$ (range $=1-\mathrm{m}$, in rows) are used or created by sub-processes $\mathrm{k}$ (range $=1-\mathrm{p}$, in columns). Matrix I contains only ones and zeros, the formers indicate inputs/outputs i are used or created by sub-process $\mathrm{k}$, the latter they are not. 
LCI data (Table 3) came from a French WWTP that can treat up to 140000 population equivalents and are provided for the annual production of $3120000 \mathrm{~kg}$ dry matter of sludge, which yields $25317 \mathrm{~kg}$ of P. Matrix I had five rows for flows of electricity, infrastructure, reactants, and $\mathrm{CO}_{2}$ and $\mathrm{N}_{2} \mathrm{O}$ emissions and three columns for $\mathrm{C}, \mathrm{N}$ and $\mathrm{P}$ removal subprocesses. Because the first two flows were used within all sub-processes and the other three were specific to P, C, and N removal, respectively, matrix I took the form: $I=\left[\begin{array}{ccc}1 & 1 & 1 \\ 1 & 1 & 1 \\ 0 & 0 & 1 \\ 1 & 0 & 0 \\ 0 & 1 & 0\end{array}\right]$

\subsubsection{Step 4. Finalising allocation factor $C_{r}$}

Allocation factor $C_{r}$ was finalised by multiplying the global allocation factor $\left(C_{g}\right)$ by matrix I (Eq. 19):

$$
\mathrm{C}_{\mathrm{i}, \mathrm{r}}=\mathrm{I} \cdot \mathrm{C}_{\mathrm{g}}
$$

As the sum of allocation factors of each input/output $\mathrm{i}$ must equal $1, \mathrm{C}_{\mathrm{r}}$ was scaled down by dividing each element in a row by the sum of each row in matrix $C_{i, r}$ (Eq. 20):

$$
\mathrm{C}_{\mathrm{r}}=\frac{\mathrm{C}_{\mathrm{i}, \mathrm{r}}}{\sum_{\mathrm{r}=1}^{\mathrm{q}} \mathrm{C}_{\mathrm{i}, \mathrm{r}}} \quad \text { (Eq. 20) }
$$

The corrected allocation factor $C_{r}$ results in a matrix in which rows represent allocation factors for each input/output $\mathrm{i}$ and columns represent allocation factors for each coproduct.

For wastewater treatment, the first and second columns in matrix $C_{r}$ represented corrected allocation factors for sludge $\left(\mathrm{C}_{\text {sludge }}\right)$ and treated water $\left(\mathrm{C}_{\text {water }}\right)$, respectively:

$$
C_{i, r}=\left[\begin{array}{ll}
0.446 & 0.554 \\
0.446 & 0.554 \\
0.085 & 0.026 \\
0.191 & 0.232 \\
0.170 & 0.296
\end{array}\right] \text {, thus, } C_{r}=\left[\begin{array}{ll}
0.45 & 0.55 \\
0.45 & 0.55 \\
0.77 & 0.23 \\
0.45 & 0.55 \\
0.37 & 0.63
\end{array}\right] \text { leading to } C_{\text {sludge }}=\left[\begin{array}{c}
0.45 \\
0.45 \\
0.77 \\
0.45 \\
0.36
\end{array}\right] \text { and } C_{\text {water }}=\left[\begin{array}{c}
0.55 \\
0.55 \\
0.23 \\
0.55 \\
0.63
\end{array}\right]
$$

Thus, based on the LCI, the $\mathrm{C}_{\text {sludge }}$ matrix indicated the percentages of environmental burdens that should be allocated to sludge production: $45 \%$ of electricity and infrastructure resources, $77 \%$ of reactant resources, $45 \%$ of $\mathrm{CO}_{2}$ emissions and $36 \%$ of $\mathrm{N}_{2} \mathrm{O}$ emissions.

\subsection{Robustness of allocation factor $\mathrm{C}_{\text {sludge }}$ for sludge production}

Sensitivity analysis was performed for allocation factor $\mathrm{C}_{\text {sludge }}$ to assess the latter's relevance for sludge production. $\mathrm{C}_{\text {sludge }}$ equals the sum of global allocation factors $\mathrm{C}_{\mathrm{g}}$ for sludge (i.e. first column of matrix $\mathrm{C}_{\mathrm{g}}$ ) and is equivalent to the 
value calculated when inputs/outputs of all sub-processes are used (i.e. $\mathrm{C}_{\text {sludge }}=0.45$ ). The sensitivity analysis focused on 11 variables used to calculate process- and product-related parameters (Tables 1 and 2). Supplementary Information provides detailed explanation of how each one's range of variation was determined.

A complete factorial experimental design was performed using R software (Isoz and Kolani, 2017) to assess the robustness of $\mathrm{C}_{\text {sludge }}$ in response to variation in these 11 variables and the relative influence of these 11 variables on it. The complete factorial design resulted in $3^{11}$ possible combinations, which yielded many values for $\mathrm{C}_{\text {sludge }}$ (box plot representation, Fig 3a). Minimum and maximum values of $\mathrm{C}_{\text {sludge }}$, which had a median value of 0.437 , varied by no more than $10 \%$, mainly because the nature of the parameters caused them to have small ranges of variation. Statistical analysis of the influence of parameters on $\mathrm{C}_{\text {sludge }}$ indicated that the stoichiometric parameters used for $\mathrm{N}$ or $\mathrm{P}$ removal had little influence. Only the number of moles of oxygen used for bacterial decay $\left(n_{O 2, \text { decay }}\right)$ had an influence (Fig. $\left.3 b\right)$, decreasing $\mathrm{C}_{\text {sludge }}$ as $n_{O 2, \text { decay }}$ increased. However, the range of variation in $n_{O 2, \text { decay }}$ varied $\mathrm{C}_{\text {sludge }}$ by only $3 \%$. Thus, the $\mathrm{C}_{\text {sludge }}$ calculated seemed relevant within the range of values used.

\subsection{Benefits of the method for LCA allocation}

The allocation factor developed in this study can be used as-is in LCA of sludge production when assessing environmental impacts of sludge-based products. However, in practice, using it requires more mathematical modelling. LCI flows (Table 3) can be represented as a square matrix (I') that contains zeros except for diagonal elements, each of which represents a flow (i.e. electricity, infrastructure resources, reactants, and $\mathrm{CO}_{2}$ and $\mathrm{N}_{2} \mathrm{O}$ emissions, respectively). This matrix must be multiplied by allocation factor $C_{r}$ (Eq. 20) so that the resulting matrix has a shape that can replace $B_{*} \cdot A_{*}^{-1}$ in Eq. 2 . In the wastewater treatment case study:

$\mathrm{I}^{\prime}=\left[\begin{array}{ccccc}3527855 & 0 & 0 & 0 & 0 \\ 0 & 0.033 & 0 & 0 & 0 \\ 0 & 0 & 36500 & 0 & 0 \\ 0 & 0 & 0 & 1431586 & 0 \\ 0 & 0 & 0 & 0 & 1133\end{array}\right]$

and Eq. 2 can be transformed as follows:

$$
\mathrm{g}_{*}=\mathrm{I}^{\prime} \cdot \mathrm{C}_{\mathrm{r}} \cdot \mathrm{f}
$$

The allocated inventory flow $\mathrm{g}_{*}$ for sludge production is calculated by considering that the vector f represents the scaled functional unit (i.e. if $25317 \mathrm{~kg}$ of $\mathrm{P}$ are produced and the functional unit is set to $1 \mathrm{~kg}$ of $\mathrm{P}$, f equals 3.95E-05): 


$$
\mathrm{g}_{*}=\left[\begin{array}{ccccc}
3527855 & 0 & 0 & 0 & 0 \\
0 & 0.033 & 0 & 0 & 0 \\
0 & 0 & 36500 & 0 & 0 \\
0 & 0 & 0 & 1431586 & 0 \\
0 & 0 & 0 & 0 & 1133
\end{array}\right] \cdot\left[\begin{array}{c}
0.45 \\
0.45 \\
0.77 \\
0.45 \\
0.36
\end{array}\right] \cdot[3.65 \mathrm{E}-05]=\left[\begin{array}{c}
62.15 \\
5.8 \mathrm{E}-07 \\
1.10 \\
25.56 \\
0.016
\end{array}\right]
$$

This simplified mathematical modelling is one way to assess environmental impacts of sludge production using a technology-oriented allocation factor.

\section{Discussion}

The importance of modelling the system and determining the process- and product-related parameters and their values are key issues in determining the developed allocation factor, and are therefore discussed below.

\subsection{Importance of system modelling in constructing $\mathrm{C}_{\text {sludge }}$}

Allocation factors depend strongly on how the system is modelled. The allocation factor for sludge production was based on a mesoscopic approach to consider the sub-processes that produce sludge. This approach allows for accurate description of system functioning because the process- and product-related parameters focus on operational process functioning and product creation, respectively. This approach is technologically oriented, and performances of wastewater treatment and mechanisms involved in sludge production are reflected in the allocation factor. Dividing the system into sub-processes, however, required a wastewater treatment expert to adequately identify and model the sub-processes as individual unit processes.

The WWTP was modelled as an aerobic activated sludge process, for which the allocation factor calculated is valid. Other biological processes are available to treat wastewater, however, such as attached growth systems, or extensive processes such as reed bed filters. Validating the allocation factor for sludge production requires in-depth analysis of such systems to identify whether the process- and product-related parameters are also valid for these systems and the allocation factor developed.

\subsection{Determining the process- and product-related parameters used to construct $\mathrm{C}_{\text {sludge }}$}

Two critical steps are necessary to construct allocation factor $\mathrm{C}_{\text {sludge }}$ : (i) identifying the process- and product-related parameters and (ii) determining their values and how to calculate $\alpha_{\mathrm{k}, \mathrm{r}}$ and $\beta_{\mathrm{j}, \mathrm{k}}$ ratios. 


\subsubsection{Identifying parameters}

From a mathematical viewpoint, there is no limit to the number of process- and product-related parameters that can be used to construct the allocation factor. Identifying these parameters is extremely important because they must be relevant and reflect the process performances. This requires selecting the parameters that influence process functioning and product creation the most. Because the process functioning is well known, the parameters can be identified with a qualitative or quantitative mechanistic approach. In the present study, the most relevant process- and product-related parameters were identified with a qualitative method that required the help of experts in corresponding technical and scientific domains. This approach ensures that appropriate parameters are used, but remains subjective because they are based on expert opinion. A quantitative method, based on process modelling, is more appropriate when the allocation factor is used to optimise processes to reduce their environmental impacts. Examples include (i) activated sludge models (Henze et al., 2000), (ii) a data-driven approach that identifies useful patterns and models using algorithms based on statistics and artificial intelligence (Wei, 2013), and (iii) empirical modelling based on artificial neural networks and multivariate polynomial regression (Raduly et al., 2015).

\subsubsection{Determining parameter values}

Once parameters are identified, the second key issue is to determine their values. In the present study, standard values from legislation for P removal and those used to calculate WWTP capacity for C and N removal were considered under the supervision of technical experts. This enables using the allocation factor for wastewater treatment systems similar to the system modelled. The allocation factor can be used as-is in LCA studies without further calculations. These standard values, however, do not consider characteristics that may be specific to certain wastewater treatment processes. This might be restrictive if the allocation factor is used with the aim of decreasing environmental impacts of sludge-based products. In this context, parameter values should come from measurements and model predictions in priority, then on expert opinion and literature data.

\subsection{Robustness of $\mathrm{C}_{\text {sludge }}$}

Determining the allocation factor comes with uncertainties. Uncertainties occur when real process operations are simplified and processes are subdivided. Identifying parameters and determining their values is also a source of uncertainty in calculating the allocation factor. Further uncertainty occurs in assuming that relationships between processand product-related parameters are linear. Linear modelling is common in LCA because process models are developed for an average operating status without considering time dependencies and substance-specific wastewater composition. It may thus oversimplify modelling of processes technologies (Köhler et al., 2007). 
To decrease the uncertainty in determining product- and process-related parameters, uncertainty analysis is recommended for the chosen parameters and the calculated ratios to highlight the robustness of the allocation factor and the most influent parameters. Determination of $\alpha_{\mathrm{k}, \mathrm{r}}$ and $\beta_{\mathrm{j}, \mathrm{k}}$ requires more caution if the allocation factor varies greatly when the processor product-related parameters vary. If the allocation factor varies little, it can be argued that determination of these process- and product-related parameters is relevant and the allocation factor is robust.

\section{Conclusion}

This study used a modelling approach to allocate environmental burdens of wastewater treatment between sludge and treated water based on the technological efficiency of the treatment processes. The approach considers possible links between processes and products according to their respective related parameters to calculate an allocation factor following a matrix-based approach. Technical and scientific expert opinions were used to determine these parameters to base allocation factor calculation on realistic data not founded on arbitrary choices. Two process-related parameters and three product-related parameters were identified and combined to calculate the allocation factor for sludge production. The allocation factor was approximately $45 \%$ and ranged from $39-49 \%$ depending on the values of each parameter in the calculation. Finally, determining these parameters requires careful consideration to avoid uncertainty. Specific models, experimental results, and expert opinion can provide relevant values for each process- and product-related parameter.

\section{References}

Alvarez-Gaitan, J.P., Peters, G.M., Short, M.D., Schulz, M., Moore, S., 2013. Understanding the impacts of allocation approaches during process based life cycle assessment of water treatment chemicals. Integrated Environmental Assessment and Management 10, 87-94.

Angenent, L.T., Karim, K., Al-Dahhan, M.H., Domiguez-Espinosa, R., 2004. Production of bioenergy and biochemicals from industrial and agricultural wastewater. Trends in Biotechnology 22, 477-485.

Azapagic, A., Clift, R., 1999a. Allocation of environmental burdens in co-product systems: Product-related burdens (Part 1). The International Journal of Life Cycle Assessment 4, 357-369.

Azapagic, A., Clift, R., 1999b. Allocation of environmental burdens in multiple-function systems. Journal of Cleaner Production 7, 101-119.

Azapagic, A., Clift, R., 2000. Allocation of environmental burdens in co-product systems: Process and product-related burdens (part 2). The International Journal of Life Cycle Assessment 5, 31-36.

Bond, T., Brouckaert, C.J., Foxon, K.M., Buckley, C.A., 2012. A critical review of experimental and predicted methane generation from anaerobic codigestion. Water Science and Technology 65, 183-189.

Bridle, T.R., Pritchard, D., 2004. Energy and nutrient recovery from sewage sludge via pyrolysis. Water Science and Technology 50, 169-175.

Canler, J.P., Choubert, J.M., 2007. Les clarifloculateurs plus particulièrement utilisés en traitement tertiaire, Dossier technique, FNDAE n³5, p. 80. 
Cao, Y., Pawlowski, A., 2012. Sewage sludge-to-energy approaches based on anaerobic digestion and pyrolysis: Brief overview and energy efficiency assessment. Renewable \& Sustainable Energy Reviews 16, 1657-1665.

CEC, 2008. Council directive of 19 November 2008 on waste and repealing certain Directives (2008/98/EC). Official Journal of the European Communities.

CEC, 2017. Report from the commission to the European parliament, the council, the European economic and social committee and the committee of the regions on the implementation of the Circular Economy Action Plan. European Commission, p. 14.

Chen, C., Habert, G., Bouzidi, Y., Jullien, A., Ventura, A., 2010. LCA allocation procedure used as an incitative method for waste recycling: An application to mineral additions in concrete. Resources, Conservation and Recycling 54, 12311240 .

Cieślik, B.M., Namieśnik, J., Konieczka, P., 2015. Review of sewage sludge management: standards, regulations and analytical methods. Journal of Cleaner Production 90, 1-15.

Cruze, N.B., Goel, P.K., Bakshi, B.R., 2014a. Allocation in life cycle inventory: partial set of solutions to an ill-posed problem. The International Journal of Life Cycle Assessment 19, 1854-1865.

Cruze, N.B., Goel, P.K., Bakshi, B.R., 2014b. Revisiting least squares techniques for the purposes of allocation in life cycle inventory. The International Journal of Life Cycle Assessment 19, 1733-1744.

Curran, M.A., 2007a. Co-product and input allocation approaches for creating life cycle inventory data: a literature review. The International Journal of Life Cycle Assessment 12, 65-78.

Curran, M.A., 2007b. Studying the effect on system preference by varying coproduct allocation in creating life-cycle inventory. Environmental Science \& Technology 41, 7145-7151.

De Gioannis, G., Muntoni, A., Polettini, A., Pomi, R., 2013. A review of dark fermentative hydrogen production from biodegradable municipal waste fractions. Waste Management 33, 1345-1361.

Degrémont, 2005. Memento technique de l'eau. Dixième édition. Lavoisier SAS.

Deronzier, G., Schétrite, S., Racault, Y., Canler, J.P., Liénard, A., Héduit, A., Duchène, P., 2001. Traitement de l'azote dans les stations d'épuration biologique des petites collectivités, Document technique FNDAE n²5, p. 79.

Egle, L., Rechberger, H., Zessner, M., 2015. Overview and description of technologies for recovering phosphorus from municipal wastewater. Resources, Conservation and Recycling 105, Part B, 325-346.

Ekvall, T., Tillman, A.-M., 1997. Open-loop recycling: Criteria for allocation procedures. The International Journal of Life Cycle Assessment 2, 155-162.

Eurostat, 2017. European statistical database. http://ec.europa.eu/eurostat/data/database

FAO, 2014. Environmental performance of animal feeds supply chains. Available at: http://www.fao.org/fileadmin/user_upload/benchmarking/docs/LEAP_Anima_feeds_DRAFT.pdf. April 2017).

Fonts, I., Gea, G., Azuara, M., Abrego, J., Arauzo, J., 2012. Sewage sludge pyrolysis for liquid production: A review. Renewable \& Sustainable Energy Reviews 16, 2781-2805.

Hadi, P., Xu, M., Ning, C., Lin, C.S.K., McKay, G., 2015. A critical review on preparation, characterization and utilization of sludge-derived activated carbons for wastewater treatment. Chemical Engineering Journal 260, 895-906.

Hahn, H., 2012. Chemical Water and Wastewater Treatment V, 8th Gothenburg Symposium September 07-09, 1998 Springer Science \& Business Media, Prague, Czech Republic, p. 414.

Hanes, R.J., Cruze, N.B., Goel, P.K., Bakshi, B.R., 2015. Allocation games: addressing the ill-posed nature of allocation in life-cycle inventories. Environmental Science \& Technology 49, 7996-8003.

Heijungs, R., 2010. Sensitivity coefficients for matrix-based LCA. The International Journal of Life Cycle Assessment 15, 511-520.

Heijungs, R., Frischknecht, R., 1998. A special view on the nature of the allocation problem. The International Journal of Life Cycle Assessment 3, 321-332. 
Heijungs, R., Suh, S., 2002. The computational structure of life cycle assessment, Kluwer, Dordrecht.

Heijungs, R., Tan, R.R., 2010. Rigorous proof of fuzzy error propagation with matrix-based LCI. The International Journal of Life Cycle Assessment 15, 1014-1019.

Henze, M., Gujer, W., Mino, T., van Loosdrechst, M., 2000. Activated Sludge Models ASM1, ASM2, ASM2d and ASM3, IWA Task Group on Mathematical Modelling for Design and Operation of Biological Wastewater Treatment. IWA Publishing, p. 122.

IDF, 2010. A common carbon footprint approach for dairy In: Bull. Int. Dairy., p 445.

ILCD Handbook, 2010. ILCD Handbook: General guide for Life Cycle Assessment - Detailed guidance, p. 417.

ISO, 2006a. ISO 14040 - Environmental management - Life cycle assessment - Principles and framework.

ISO, 2006b. ISO 14044 - Environmental management - Life cycle assessment - Requires and guidelines.

Isoz, V., Kolani, D., 2017. R - statistical software, one software to Rule them all - Cookbook, p. 1662.

Johansson, K., Perzon, M., Froling, M., Mossakowska, A., Svanstrom, M., 2008. Sewage sludge handling with phosphorus utilization: life cycle assessment of four alternatives. Journal of Cleaner Production 16, 135-151.

Jung, J., von der Assen, N., Bardow, A., 2013. Comparative LCA of multi-product processes with non-common products: a systematic approach applied to chlorine electrolysis technologies. The International Journal of Life Cycle Assessment $18,828-839$.

Jung, J., von der Assen, N., Bardow, A., 2014. Sensitivity coefficient-based uncertainty analysis for multi-functionality in LCA. The International Journal of Life Cycle Assessment 19, 661-676.

Kalinci, Y., Hepbasli, A., Dincer, I., 2009. Biomass-based hydrogen production: A review and analysis. International Journal of Hydrogen Energy 34, 8799-8817.

Kargbo, D.M., 2010. Biodiesel Production from Municipal Sewage Sludges. Energy \& Fuels 24, 2791-2794.

Kim, S., Overcash, M., 2000. Allocation Procedure in Multi-Output Process: An Illustration of ISO 14041. The International Journal of Life Cycle Assessment 5, 221-228.

Köhler, A., Hellweg, S., Recan, E., Hungerbühler, K., 2007. Input-dependent life-cycle inventory model of industrial wastewater-treatment processes in the chemical sector. Environmental Science \& Technology 41, 5515-5522.

Lederer, J., Rechberger, H., 2010. Comparative goal-oriented assessment of conventional and alternative sewage sludge treatment options. Waste Management 30, 1043-1056.

Mackenzie, S.G., Leinonen, I., Kyriazakis, I., 2017. The need for co-product allocation in the life cycle assessment of agricultural systems-is "biophysical" allocation progress? The International Journal of Life Cycle Assessment 22, 128137.

Majeau-Bettez, G., Wood, R., Strømman, A.H., 2014. Unified theory of allocations and constructs in life cycle assessment and input-output analysis. Journal of Industrial Ecology 18, 747-770.

Manara, P., Zabaniotou, A., 2012. Towards sewage sludge based biofuels via thermochemical conversion - A review. Renewable \& Sustainable Energy Reviews 16, 2566-2582.

Marvuglia, A., Cellura, M., Heijungs, R., 2010. Toward a solution of allocation in life cycle inventories: the use of leastsquares techniques. The International Journal of Life Cycle Assessment 15, 1020-1040.

MEEM, 2016. Économie circulaire - Les avancées de la loi de transition énergétique pour la croissance verte - Plan de réduction et de valorisation des déchets 2025 - Contribution à la stratégie nationale de transition vers l'économie circulaire, p. 28.

Mehta, C.M., Khunjar, W.O., Nguyen, V., Tait, S., Batstone, D.J., 2015. Technologies to Recover Nutrients from Waste Streams: A Critical Review. Critical Reviews in Environmental Science and Technology 45, 385-427.

Mills, N., Pearce, P., Farrow, J., Thorpe, R.B., Kirkby, N.F., 2014. Environmental \& economic life cycle assessment of current \& future sewage sludge to energy technologies. Waste Management 34, 185-195. 
Mudhoo, A., Forster-Carneiro, T., Sanchez, A., 2011. Biohydrogen production and bioprocess enhancement: A review. Critical Reviews in Biotechnology 31, 250-263.

Pelletier, N., Ardente, F., Brandão, M., De Camillis, C., Pennington, D., 2015. Rationales for and limitations of preferred solutions for multi-functionality problems in LCA: is increased consistency possible? The International Journal of Life Cycle Assessment 20, 74-86.

Pradel, M., Aissani, L., Villot, J., Baudez, J.-C., Laforest, V., 2016. From waste to added value product: towards a paradigm shift in life cycle assessment applied to wastewater sludge - a review. Journal of Cleaner Production 131, 6075.

Qasim, S.R., 1998. Wastewater Treatment Plants: Planning, Design, and Operation. Second Edition, CRC Press.

Raduly, B., Capodaglio, A.G., Vacari, D.A., 2015. Empirical modelling of wastewater treatment processes - An approach to model reduction and integration, p. 7. Available at: http://apuss.insa-lyon.fr/CityNet/paper_botond_raduly.pdf

Rahman, M.M., Salleh, M.A.M., Rashid, U., Ahsan, A., Hossain, M.M., Ra, C.S., 2014. Production of slow release crystal fertilizer from wastewaters through struvite crystallization - A review. Arabian Journal of Chemistry 7, 139-155.

Remy, C., 2015. Life Cycle Assessment of selected processes for P recovery from sewage sludge, sludge liquor, or ash, Report from P-Rex project, p. 86.

Rulkens, W., 2008. Sewage sludge as a biomass resource for the production of energy: Overview and assessment of the various options. Energy \& Fuels 22, 9-15.

Siddiquee, M.N., Rohani, S., 2011. Lipid extraction and biodiesel production from municipal sewage sludges: A review. Renewable \& Sustainable Energy Reviews 15, 1067-1072.

Smith, K.M., Fowler, G.D., Pullket, S., Graham, N.J.D., 2009. Sewage sludge-based adsorbents: A review of their production, properties and use in water treatment applications. Water Research 43, 2569-2594.

Stricker, A.E., Héduit, A., 2010. Phosphore des eaux usées - Etat des lieux et perspectives, Rapport final, OnemaCemagref, p. 54.

Suh, S., Weidema, B.P., Schmidt, J.H., Heijungs, R., 2010. Generalized make and use framework for allocation in life cycle assessment. Journal of Industrial Ecology 14, 335-353.

Tyagi, V.K., Lo, S.-L., 2013. Sludge: A waste or renewable source for energy and resources recovery? Renewable \& Sustainable Energy Reviews 25, 708-728.

van der Werf, H.M.G., Nguyen, T.T.H., 2015. Construction cost of plant compounds provides a physical relationship for co-product allocation in life cycle assessment. The International Journal of Life Cycle Assessment 20, 777-784.

Wang, H., Brown, S.L., Magesan, G.N., Slade, A.H., Quintern, M., Clinton, P.W., Payn, T.W., 2008. Technological options for the management of biosolids. Environmental Science and Pollution Research 15, 308-317.

Wang, R., Work, D., 2014. Application of robust optimization in matrix-based LCI for decision making under uncertainty. The International Journal of Life Cycle Assessment 19, 1110-1118.

Wei, X., 2013. Modelling and optimization of wastewater treatment process with a data-driven approach. University of Iowa. Available at : http://ir.uiowa.edu/cgi/viewcontent.cgi?article=4788\&context=etd

Weidema, B., 2017. In Search of a Consistent Solution to Allocation of Joint Production. Journal of Industrial Ecology, 11 .

Xu, G., Zou, J., Li, G., 2008. Ceramsite Made with Water and Wastewater Sludge and its Characteristics Affected by $\mathrm{SiO} 2$ and A12O3. Environmental Science \& Technology 42, 7417-7423.

Yoshida, H., Christensen, T.H., Scheutz, C., 2013. Life cycle assessment of sewage sludge management: A review. Waste Manage. Res. 31, 1083-1101. 